\title{
Gastrointestinal stromal tumor of the stomach with lymph node metastasis
}

\author{
Aras Emre Canda*1, Yucel Ozsoy ${ }^{1}$, Olcay Ak Nalbant ${ }^{2}$ and Ozgul Sagol ${ }^{3}$
}

\begin{abstract}
Address: ${ }^{1}$ Department of Surgery, Manisa State Hospital, Manisa, Turkey, ${ }^{2}$ Department of Pathology, Manisa State Hospital, Manisa, Turkey and ${ }^{3}$ Department of Pathology, Dokuz Eylul University School of Medicine, Izmir, Turkey

Email: Aras Emre Canda* - emre.canda@deu.edu.tr; Yucel Ozsoy - dryucelozsoy@hotmail.com; Olcay Ak Nalbant - olcaynalbant@yahoo.com; Ozgul Sagol - ozgul.sagol@deu.edu.tr

* Corresponding author
\end{abstract}

Published: 5 September 2008

World Journal of Surgical Oncology 2008, 6:97 doi:10.1 186/1477-78/9-6-97

This article is available from: http://www.wjso.com/content/6/l/97

(C) 2008 Canda et al; licensee BioMed Central Ltd.

This is an Open Access article distributed under the terms of the Creative Commons Attribution License (http://creativecommons.org/licenses/by/2.0), which permits unrestricted use, distribution, and reproduction in any medium, provided the original work is properly cited.
Received: 26 April 2008

Accepted: 5 September 2008

\begin{abstract}
Background: Lymph node (LN) metastasis of gastrointestinal stromal tumors (GIST) is unusual. Unlike gastric adenocarcinomas, routine lymphadenectomy is not recommended unless there is no suspicion for LN metastasis. Herein, we report a case of GIST of the stomach with LN metastasis treated with distal gastrectomy with perigastric LN dissection followed by adjuvant imatinib therapy.
\end{abstract}

Case presentation: A 32-year-old female presented with anemia. Diagnostic investigations including thoracoabdominopelvic computed tomography (CT) scan and gastroscopy revealed a 8 $\mathrm{cm}$ gastric antral submucosal tumor without any metastasis. Enlarged periantral LNs were detected during laparotomy and patient underwent distal gastrectomy with en bloc perigastric LN dissection. Pathologic investigation revealed antral stromal tumor with high mitotic and Ki-67 index. Lymph node metastasis was observed in 7 of 12 resected perigastirc nodes. Immunohistochemically, tumor cells were positive for CDI I7. She was diagnosed as high grade gastric GIST due to the presence of LN metastasis, large tumor size and unfavorable histopathologic features thus underwent adjuvant imatinib treatment ( $400 \mathrm{mg}$, daily). No recurrence or metastasis has been detected during a I2-month of postoperative follow-up.

Conclusion: Surgery remains the mainstay of treatment in patients with localized, resectable GISTs. Although lymphatic metastasis rarely occurs in patients with GIST, LN dissection should be considered for patients with any suspicion of nodal metastasis. Adjuvant imatinib treatment is recommended according to the well defined prognostic factors.

\section{Background}

Gastrointestinal stromal tumor (GIST) is the most common mesenchymal tumor of the gastrointestinal tract. They most commonly arise from the stomach; which account for $\sim 1 \%$ of gastric malignancies [1]. Their origin has been proposed to be the intestinal cells of Cajal [2]. The mainstay of primary treatment for GIST is R0 resec- tion. Unlike gastric adenocarcinomas, routine lymphadenectomy is not recommended unless there is no suspicion of intraoperative lymph node (LN) metastasis. Approximately $95 \%$ of GISTs express mutation in the $C$ KIT proto-oncogen [3]. A tyrosine kinase inhibitor, Imatinib mesylate (Glivec ${ }^{\circledR}$; Novartis Pharma, Istanbul, Türkiye) which blocks KIT proteins is the main agent for 
targeted adjuvant and neoadjuvant treatment as well as used for palliation. Risk assessment after resection determines the need for adjuvant imatinib treatment. Currently, main indications for adjuvant imatinib treatment are unresectable or metastatic disease [4]. Herein, we report a case of GIST of the stomach with $\mathrm{LN}$ metastasis and discussed its management and follow-up.

\section{Case presentation}

A 32-year-old female with anemia was referred to our hospital. Her past medical history was insignificant. Gastroscopy demonstrated an antral submucosal tumor. Thoracoabdominopelvic computed tomography (CT) scan showed an $8 \mathrm{~cm}$ intramural mass with no distant metastasis (Figure 1). At laparotomy, few enlarged periantral LNs around the tumor reaching up to $1 \mathrm{~cm}$ were observed. Distal gastrectomy with en bloc perigastric LN dissection was performed. Postoperative course of the patient was uneventful.

Histopathological examination showed an antral stromal tumor which was $8 \times 8 \times 4 \mathrm{~cm}$ in size. Mitotic index was 25 mitoses/50 high-power fields (hpf) and MiB1 (Ki-67) index was higher than 10\% (Figure 2a). No necrosis and infiltration to adjacent structures was observed. Immunohistochemically, tumor cells were positive for CD117 $(+++)$ and CD34 (+++); negative for desmin and S-100 (Figure 2b). Lymph node metastasis was observed in 7 of 12 resected perigastirc nodes (Figure 2c).

She was diagnosed as high grade gastric GIST due to the presence of LN metastasis, large tumor size and unfavorable histopathological features (high mitotic index and Ki67 index). Therefore, adjuvant imatinib treatment

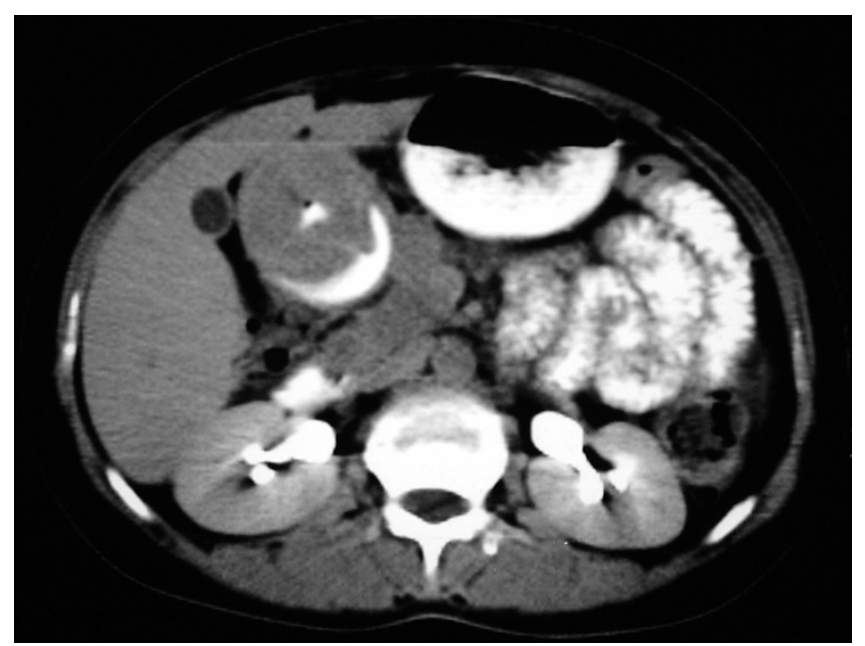

Figure I

Abdominal CT scan: axial view showing an $8 \mathrm{~cm}$ in size antral intramural mass.
(Glivec ${ }^{\circledR} 400 \mathrm{mg}$, daily) was initiated and has been continued to date. The drug was well tolerated by the patient and no adverse effect was observed. No recurrence or metastasis has been detected during a 12-month postoperative follow-up.

\section{Discussion}

GISTs are distinctive subgroup of gastrointestinal mesenchymal tumors which express CD117 or platelet derived growth factor receptor alpha (PDGFRA) $[3,5]$. Due to the recent advances in immunohistochemical and molecular techniques, its diagnostic incidence has been increased. Most of the patients with GIST are symptomatic and bleeding due to mucosal ulceration is the most common symptom [6].

Surgery remains the mainstay of treatment in patients with localized, resectable GISTs. The principle of surgery for GISTs is R0 resection of the tumor. Tumor rupture or R1 resection of the primary tumor has a negative impact on disease free survival [7]. Aparicio et al. [8] reported lower local recurrence rates with segmental resection of the stomach compared to wedge gastric resection even in patients whom R0 resection was obtained. Lymphatic metastasis rarely occurs $(0-3.4 \%)$ in patients with GIST $[1,9,10]$. Special care was taken during the histopathological examination for differentiation of nodal metastasis from peritoneal dissemination of the tumor. Although there is limited experience with management of GISTs with LN metastasis; LN dissection should be considered for patients with any suspicion of nodal metastasis. In our patient, because the enlarged LNs were located at the periantral region, we performed a limited lymphatic dissection (stations 3-9). This surgical approach documented synchronous nodal metastasis status thus contributed for decision of the adjuvant treatment planning. The postoperative course of the patient was uneventful.

Reported recurrence rates of $17-21 \%$ and 5-year survival rates of $48-70 \%$ even in patients with resectable GIST emerges the need for an adjuvant treatment [8,11-18]. The American Collage of Surgeons Oncology Group (ACOSOG) Z9001 trial is a randomized trial of imatinib versus placebo administered for one year following complete resection of a primary GIST which demonstrated a significant improvement in recurrence free survival with imatinib [19].

Currently, there is no accepted staging system for GISTs. Tumor size, location, mitotic rate, C-KIT and PDGFRA genotype are the major determinants of malignant potential of the tumor which have significant impact on prognosis [20-22]. A practical grading system for GIST after surgical resection was proposed by Bucher et al. [22] including 5 minor (tumor size $\geq 5 \mathrm{~cm}$, mitotic index $\geq 5$ 


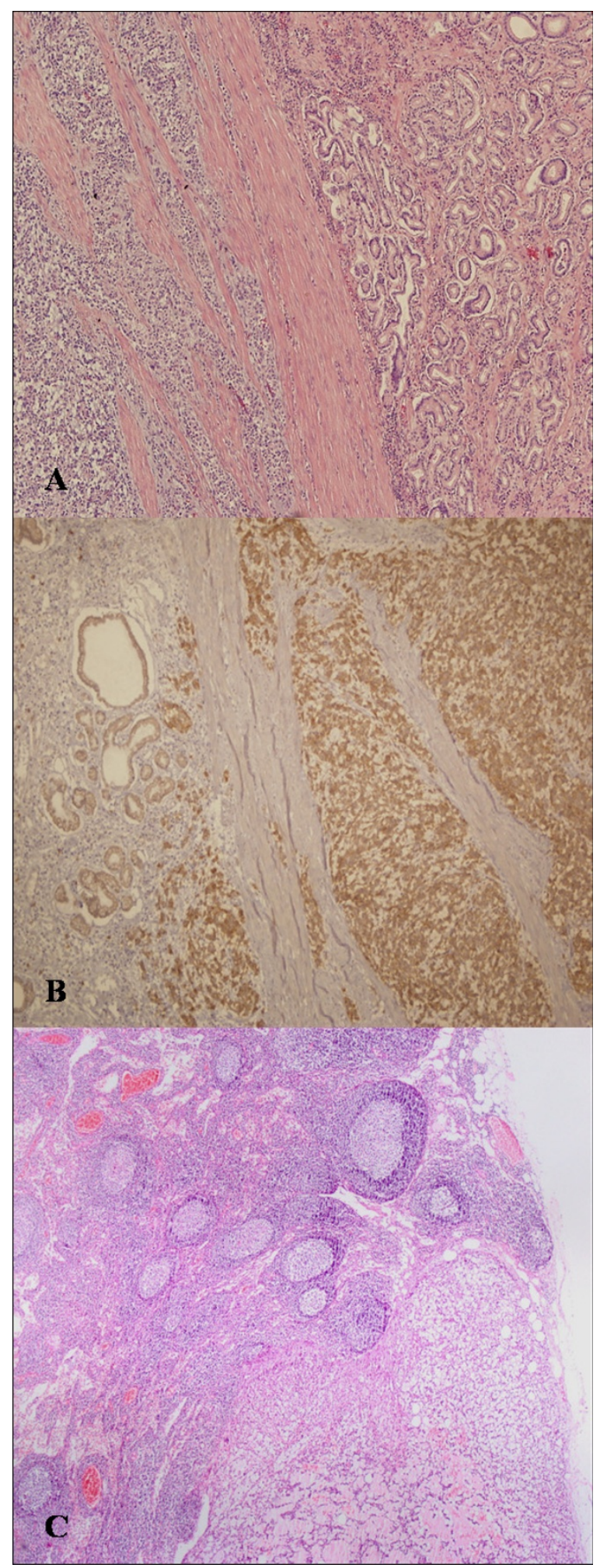

\section{Figure 2}

The histopathological examination of the tumor.A: A photomicrograph of the tumor showing epithelioid cells with prominent pleomorphism; mitotic index was 25 mitoses/50 hpf and MiBI (Ki-67) index was higher than I0\% (H\&E stain). B: Immunoreactivity for CDII7 of the tumor cells. C: A photomicrography of a lymph node metastasis (H\&E stain). 
mitoses/50 hpf, presence of necrosis, infiltration of adjacent structures, and MiB1 index $>10 \%$ ) and two major (presence of LN invasion and/or metastasis) criteria. Tumors having less than four minor criteria were classified as low grade GIST and tumors having four or five minor criteria or one major criterion were classified as high grade GIST.

It is not well established which patients will benefit from adjuvant imatinib treatment and the duration of treatment after complete resection of the primary GIST. Several recent trials have directed efforts to determine which patients may be more likely to benefit from adjuvant imatinib treatment and its duration. Bucher et al. [22] showed a correlation between the staging system and disease free survival and patient survival after primary surgery. They propose adjuvant imatinib treatment for high grade GIST patients. European Organization for Research and Treatment of Cancer (EORTC) 62024 phase-III ongoing trial randomizes patients with intermediate- and highrisk GIST in whom complete macroscopic resection achieved for treatment with imatinib (400 mg, daily) $v s$. placebo for 2 years. In ACOSOG Z9001 phase-III trial, adjuvant treatment is recommended for at least 12 months although the optimal duration has not yet been determined [19].

\section{Conclusion}

Surgery remains the mainstay of treatment in patients with localized, resectable GISTs. Although lymphatic metastasis rarely occurs in patients with GIST, LN dissection should be considered for patients with suspicion of nodal metastasis. Due to the presence of three minor and one major unfavorable prognostic factors, we considered our patient as high grade GIST thus initiated adjuvant imatinib treatment. We will consider the duration of imatinib treatment according to drug's tolerability and patient's clinical outcome and due to future scientific evidence.

\section{List of abbreviations}

GIST: Gastrointestinal stromal tumors; CT: Computed tomography; hpf: High-power fields; PDGFRA: Platelet derived growth factor receptor alpha; ACOSOG: American Collage of Surgeons Oncology Group; EORTC: European Organization for Research and Treatment of Cancer.

\section{Competing interests}

The authors declare that they have no competing interests.

\section{Authors' contributions}

AEC drafted the manuscript, YO helped in preparation and editing of the manuscript, ON wrote the pathological part of the manuscript and OS performed the IHC and contributed the IHC part of the manuscript and photom- icrographs. All authors read and approved the final manuscript.

\section{Consent}

Written consent was obtained from the patient for publication of this study.

\section{Acknowledgements}

The authors thank Cem Terzi and Ugur Yilmaz from Dokuz Eylul University, Izmir, Turkey and Safak Yuksel from Manisa State Hospital, Manisa, Turkey for clinical contribution to the case.

\section{References}

I. Lehnert T: Gastrointestinal sarcoma (GIST) - a review of surgical management. Ann Chir Gynaecol 1998, 87:297-305.

2. Kindblom LG, Remotti HE, Aldenborg F, Meis-Kindblom JM: Gastrointestinal pacemaker cell tumor (GIPACT): gastrointestinal stromal tumors show phenotypic characteristics of the interstitial cells of Cajal. Am J Pathol 1998, 152:1259-1269.

3. Corless CL, Fletcher JA, Heinrich MC: Biology of gastrointestinal stromal tumors. J Clin Oncol 2004, 22:3813-3825.

4. NCCN Practice Guidilenes in Oncology - v.3.2007 [http:// www.nccn.org]

5. Heinrich MC, Corless CL, Duensing A, McGreevey L, Chen CJ, Joseph N, Singer S, Griffith D], Haley A, Town A, Demetri GD, Fletcher CD, Fletcher JA: PDGFRA activating mutations in gastrointestinal stromal tumors. Science 2003, 299:708-710.

6. Gold JS, De Matteo RP: Combined surgical and molecular therapy: the gastrointestinal stromal tumor model. Annals of Surgery 2006, 244: $176-184$.

7. Rutkowski P, Debiec-Rychter M, Nowecki ZI, Wozniak A, Michej W, Limon J, Siedlecki JA, Jerzak Vel Dobosz A, Grzesiakowska U, Nasierowska-Guttmejer A, Sygut J, Nyckowski P, Krawczyk M, Ruka W: Different factors are responsible for predicting relapses after primary tumors resection and for imatinib treatment outcomes in gastrointestinal stromal tumors. Med Sci Monit 2007, 13:CR5I5-522.

8. Aparicio T, Boige V, Sabourin JC, Crenn P, Ducreux M, Le Cesne A, Bonvalot S: Prognostic factors after surgery of primary resectable gastrointestinal stromal tumors. Eur J Surg Oncol 2004, 30:1098-1103.

9. Tashiro T, Hasegawa T, Omatsu M, Sekine S, Shimoda T, Katai H: Gastrointestinal stromal tumor of the stomach showing lymph node metastases. Histopathology 2005, 47:438-439.

10. Zwan SM Van der, De Matteo RP: Gastrointestinal stromal tumor. 5 years later. Cancer 2005, 104: I78I- 1788.

II. DeMatteo RP, Lewis JJ, Leung D, Mudan SS, Woodruff JM, Brennan MF: Two hundred gastrointestinal stromal tumors: recurrence patterns and prognostic factors for survival. Ann Surg 2000, 23I:5I-58.

12. Ng EH, Pollock RE, Munsell MF, Atkinson EN, Romsdahl MM: Prognostic factors influencing survival in gastrointestinal leiomyosarcomas. Implications for surgical management and staging. Ann Surg 1992, 21 5:68-77.

13. McGrath PC, Neifeld JP, Lawrence WJ, Kay S, Horsley JS, Parker GA: Gastrointestinal sarcomas. Analysis of prognostic factors. Ann Surg 1987, 206:706-710.

14. Shiu MH, Farr GH, Papachristou DN, Hajdu SI: Myosarcomas of the stomach: natural history, prognostic factors and management. Cancer 1982, 49:177-187.

15. Akwari OE, Dozois RR, Weiland LH, Beahrs OH: Leiomyosarcoma of the small and large bowel. Cancer 1978, 42:1375-1384.

16. Bucher P, Villiger P, Egger J, Buhler L, Morel P: Management of gastrointestinal stromal tumours: from diagnosis to treatment. Swiss Med Wkly 2004, 134: I45-I53.

17. Nilsson B, Bumming P, Meis-Kindblom JM, Odén A, Dortok A, Gustavsson B, Sablinska K, Kindblom LG: Gastrointestinal stromal tumors: the incidence, prevalence, clinical course, and prognostication in the preimatinib mesylate era - a populationbased study in western Sweden. Cancer 2005, 103:821-9. 
18. lesalnieks I, Rummele P, Dietmaier W, lesalnieks I, Rummele P, Dietmaier W: Factors associated with disease progression in patients with gastrointestinal stromal tumors in the preimatinib era. Am J Clin Pathol 2005, 1 24:740-8.

19. DeMatteo R, Owzar K, Maki R, Pisters P, Blackstein M, Antonescu C, Blanke C, Demetri G, von Mehren M, Ballman K, the American College of Surgeons Oncology Group (ACOSOG) Intergroup Adjuvant GIST Study Team: Adjuvant imatinib mesylate increases recurrence free survival (RFS) in patients with completely localized primary gastrointestinal stromal tumor (GIST): North American Intergroup Phase III trial ACOSOG Z900I [abstract]. Proc Am Soc Clin Oncol 2007. Abstract No 10079

20. Raut CP, DeMatteo RP: Prognostic factors for primary GIST: prime time for personalized therapy? Ann Surg Oncol 2008, 15:4-6.

21. DeMatteo RP, Gold JS, Saran L, Gönen M, Liau KH, Maki RG, Singer $S$, Besmer P, Brennan MF, Antonescu CR: Tumor mitotic rate, size, and location independently predict recurrence after resection of primary gastrointestinal stromal tumor (GIST). Cancer 2008, I I 2:608-15.

22. Bucher P, Egger JF, Gervaz P, Ris F, Weintraub D, Villiger P, Buhler $\mathrm{LH}$, Morel $\mathrm{P}$ : An audit of surgical management of gastrointestinal stromal tumours (GIST). Eur J Surg Oncol 2006, 32:3 I 0-4.

Publish with Bio Med Central and every scientist can read your work free of charge

"BioMed Central will be the most significant development for disseminating the results of biomedical research in our lifetime. "

Sir Paul Nurse, Cancer Research UK

Your research papers will be:

- available free of charge to the entire biomedical community

- peer reviewed and published immediately upon acceptance

- cited in PubMed and archived on PubMed Central

- yours - you keep the copyright

Submit your manuscript here:

http://www.biomedcentral.com/info/publishing_adv.asp 